\title{
Metallothionein as a Biomarker to Assess the Effects of Pollution on Indian Major Carp Species from Wastewater-Fed Fishponds of East Calcutta Wetlands (a Ramsar Site)
}

\author{
Utpal Singha Roy ${ }^{1}$, Buddhadeb Chattopadhyay ${ }^{2}$, Siddhartha Datta ${ }^{3}$ and \\ Subhra Kumar Mukhopadhyay ${ }^{4}$ \\ ${ }^{1}$ Department of Zoology, Durgapur Government College, India \\ ${ }^{2}$ Ecotoxicology Laboratory, Government College of Engineering and Leather Technology, India \\ ${ }^{3}$ Department of Chemical Engineering, Jadavpur University, India \\ ${ }^{4}$ Department of Zoology, Hooghly Mohsin College, India \\ crossref http://dx.doi.org/10.5755/j01.erem.58.4.660
}

(received in September, 2011, accepted in December, 2011)

\begin{abstract}
Metals are one of the major chemical toxicants that can perturb environmental homogeneity by their prolonged persistence and complex interactions. Bioaccumulation of any metal above its threshold level invariably results in stress often leading to irreversible physiological conditions. The present investigation was carried out to study the potential stress that fish species are facing in wastewater-fed (contaminated) fishponds in East Calcutta Wetlands (ECWs), manifested in total protein and metallothionein (MT) concentrations. Indian major carps (IMCs) - rohu (Labeo rohita), katla (Catla catla) and mrigel (Cirrhinus mrigala) were used as suitable fish models. Total protein concentration of different fish tissues were found to be always lower in wastewater-fed fishponds when compared to fish tissues from freshwater-fed (uncontaminated) fishponds, while an indirect enzyme-linked immunosorbent assay (ELISA) revealed a higher expression of MT in all the fish tissues collected from wastewater-fed fishponds. Major significances drawn from the present study were that fish species cultivated in east Calcutta wetland, with its ecosystem being under a potential threat of contamination and stress induced by composite effluents, could lead to adverse physiological conditions. Moreover, these findings could be important in terms of designing biomarkers for an early environmental warning system and also for monitoring fish health.
\end{abstract}

Key words: metallothionein, heavy metals, East Calcutta Wetlands, biomonitoring, Indian major carps.

\section{Introduction}

Urbanization and industrialization have persistently contaminated most of the natural environment, and consequently major cities around the globe are under a budding threat of pollution. Wetland ecosystems are the most productive and diverse ecosystems with multifarious functions but are fragile in nature and indiscriminate anthropogenic activities have resulted in the conversion of wetlands worldwide. Wetland ecosystems that receive composite effluents tinted with heavy metals are of prime environmental concern especially for the biotic components that interact with the contaminated aquatic environment (Abdelmeguid et al. 2002; Wong 2003; Raychaudhuri et al. 2008). In the eastern fringe of city Calcutta (recently renamed as Kolkata) there lies East Calcutta Wetland, a Ramsar site (No. 1208) in West Bengal, India (lat $22^{\circ} 33^{\prime}-22^{\circ} 40^{\prime} \mathrm{N}$, long $\left.88^{\circ} 25^{\prime}-88^{\circ} 35^{\prime} \mathrm{E}\right)$, the biggest urban wetland ecosystem covering around 12,771 ha area. This wetland receives untreated industrial run-off from almost 6000 large- and small-scale industrial establishments (including tanneries) along with Calcutta metropolitan's (12 million inhabitants) domestic sewage throughout the year. Nearly 50,000 
$\mathrm{m}^{3}$ of contaminated composite effluent traverses through a web of canals into the wetlands each day that has been effectively utilized by local fisherman for better yield in pisciculture in an informal indigenous method (Ghosh 2004). Spread over $3,832.27$ ha (over $30 \%$ of the total wetland area) are 286 large wastewater-fed fish ponds (locally known as Bheris), producing nearly 10,915 metric tons of fish annually (Chattopadhyay et al. 2002). Thus cultivated fish species along with other biota thriving in and around ECW ecosystems are under potential threat of elemental contamination. Bioaccumulation of hazardous metals in different fish tissues cultivated in contaminated areas around the world is on record (Jana and Sahana 1988; Canli and Erdem 1994; Kalay and Canli 2000; Rauf et al. 2009) and previous findings of our research lab have shown a higher accumulation pattern of trace metals in tissues of cichlids (Chatterjee et al. 2006) and IMCs (Aich et al. 2011) from wastewater-fed fishponds of the East Calcutta Wetlands.

Stress caused by both bio-active and non-bioactive metals induces a variety of complex changes in fish physiology and the possible consequent physiological alterations are also on record (Sorensen 1991; Heath 1995; Cicik and Engin 2005; Farombi et al. 2007). Since metals are non-biodegradable in nature, the only possibility for biota to avoid metal poisoning is by reducing the metal uptake rate, chelating the metal with some ligand or by increasing the rate of excretion. Metallothionein (MT) is a ubiquitous, low molecular weight, cysteine-rich
$(>30 \%)$ protein that avidly binds various transition elements, especially group IB and IIB metals (Waalkes et al. 1984; Hamer 1986; Olsson et al. 1990). Although the precise functions of MT is not clear, the protein is generally regarded to be involved in intracellular homeostasis of $\mathrm{Cu}$ and $\mathrm{Zn}$, enzyme activation, the acute phase response to infections, free radical scavenging and detoxification of metals (Karin 1985; Hamer 1986; Bremner and Beattie 1990; Roesijadi 1996). Since metallothionein is induced by metals it has been proposed as an excellent environmental biomarker (Linde-Arias et al. 2008).

The present investigation was carried out to assess the effects of pollution loads on different fish tissues of IMCs from wastewater-fed fishponds of ECWs manifested in total protein and metallothionein expression and to compare it to that of fish species collected from unpolluted control sites. Indian major carps (IMCs) - rohu (Labeo rohita), katla (Catla catla) and mrigel (Cirrhinus mrigala) were taken as test species because these are the most popularly cultured fish species in this part of the world due to their huge market demand. Also, the differential utilization of physical and trophic state by these species has been found to play an important role in differential metal accumulation from ECWs (Aich et al. 2011). Thus during the present investigation it has been also observed whether the differential accumulation pattern of trace metals could result in differential total protein and MT synthesis and expression in different fish tissues.

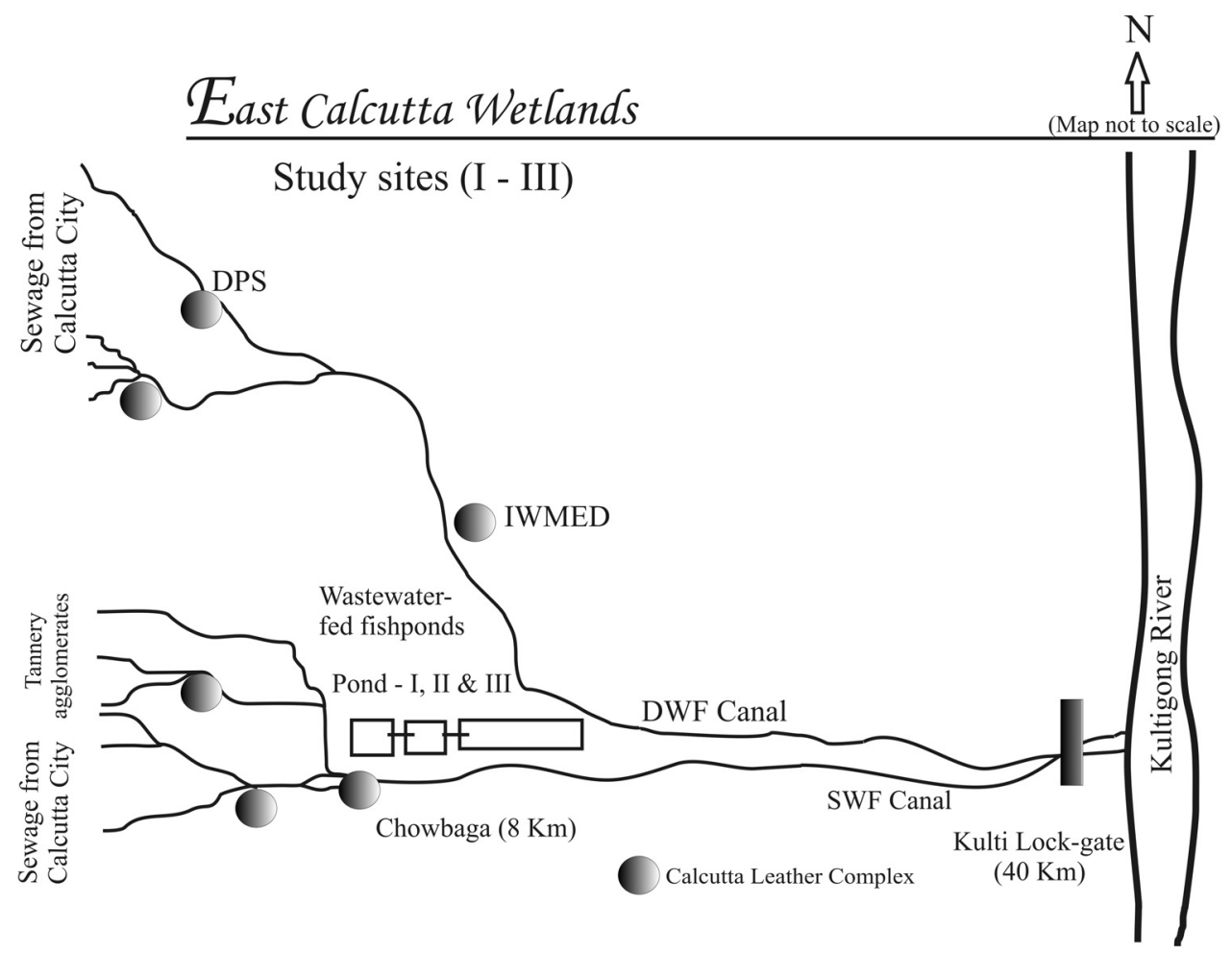

Fig. 1. Study sites showing major wastewater carrying canals in the East Calcutta Wetlands and the contaminated study sites (three wastewater-fed fishponds) for collection of abiotic and biotic samples 


\section{Materials and methods}

\subsection{Study area}

Samples were collected from three wastewaterfed fishponds located in and around the Chowbaga region, nearly $8 \mathrm{~km}$ downstream from the source of the Storm Weather Flow (SWF) canal in the ECW ecosystem (Fig. 1). Preference was given to that site as it was the merging site for municipal sewage with industrial wastewater making it altogether a composite effluent. This almost untreated raw wastewater has been effectively utilized by local fishermen in an informal, indigenous pattern for pisciculture.

\subsection{Sample collection}

Eighteen mature IMCs (six each of rohu, katla and mrigel) were collected from three wastewater-fed fishponds ( 2 individuals of 3 species from each pond). Yearlings of fish specimen of both sexes in equal proportion weighing $80 \pm 20 \mathrm{~g}$ were collected and were anesthetized with MS222 immediately and later dissected for livers, gills, muscles and brains. Control specimens (six each of rohu, katla and mrigel) for comparison, weighing $75 \pm 20 \mathrm{~g}$, were similarly collected from three natural-water-fed fishponds, free from any effluent contamination, located at Ashoknagar, West Bengal, India (about $60 \mathrm{~km}$ west of the contaminated sampling sites). The total sampling was replicated for four times for avoiding possible sampling errors.

\subsection{Measurement of metallothionein}

The anesthetized fish specimens collected both from contaminated and uncontaminated sites were dissected for livers, gills, muscles and brains. Soluble tissue extracts were prepared by homogenizing the tissue with $35 \% \mathrm{w} / \mathrm{v}$ of homogenization buffer $(50 \mathrm{~mm}$ Tris-HCL, $\mathrm{pH} 7.4$; containing .1 mM PMSF, $0.5 \mathrm{mM}$ DTT and $150 \mathrm{mM} \mathrm{NaCl}$ ) in a Teflon homogenizer at $1000-1200 \mathrm{rpm}$. The homogenates were centrifuged at $12,000 \mathrm{~g}$ for 40 minutes at $4^{\circ} \mathrm{C}$. Supernatants were collected carefully and after suitable dilution with PBS (pH 7.4) (final concentration $20 \mu \mathrm{g} / \mathrm{mL}$ ) $100 \mu \mathrm{L}$ of tissue homogenate were coated on the wall of a 96well PVC micro titer plate, sealed and kept at $4^{\circ} \mathrm{C}$ overnight.

Standard ELISA protocol (Derango and Page 1996) was applied to measure the metallothionein content. Primary antibody against metallothionein (Ab 36882) and HRP tagged secondary antibody (Ab 6721) were purchased from Abcam, UK. TMB (SRL) was used as the substrate against HRP along with 5\% $\mathrm{H}_{2} \mathrm{O}_{2}$. An automatic micro titer plate ELISA reader (LabLife-elite 96s Microplate ELISA reader, Wipro, India) was used to measure the absorbance at $650 \mathrm{~nm}$. A second reading was also noted at $450 \mathrm{~nm}$ after addition of $2.0 \mathrm{M} \mathrm{H}_{2} \mathrm{SO}_{4}$ which stops the reaction. A standard curve was generated each time the assay was performed by metallothionein standard (Sigma M 7641, USA). Back ground, non-specific binding was assessed through negative control wells that received all the components except tissue homogenate. Hornitzky and Searson (1986) were followed to obtain the ELISA values which were plotted in the regression curve obtained from a standard curve to get the high precision metallothionein value.

\subsection{Measurement of total protein content}

The protein content of various tissue fractions was calculated after Lowry et al. (1951) using bovine serum albumin as standard and absorbance was recorded by using a UV-Vis spectrophotometer (Perkin Elmer Lambda 25).

\subsection{Reagents used}

All gravimetric analysis, reagents and standard preparation were performed using Mettler AE 240 monopan electronic balance and all the reagents used were of analytical grade and obtained from MERCK, Germany, if otherwise not mentioned.

\subsection{Statistical analysis}

Statistical analysis for significant difference in total protein and MT expression among different fish species from respective controls for the same time period have been indicated by asterisks $(*)(p<0.05$, ANOVA with Tukey's comparisons) was performed using statistical software SPSS release 10.0; 1997). Graphical plots were made by using SciDAVis release $0.2 .0 ; 2010$.

\section{Results and discussion}

The metal concentrations in wastewater-fed fishponds of ECWs are sufficiently indicative of distinct adverse physiological responses of the fish thriving therein. Proteins are the most important macromolecules that control crucial functions in essentially all biological processes. In fish species protein acts as the major macronutrient that controls energy gain or loss (Diana 1982) and an increase in pollutants, including heavy metals, often results in decreased total protein concentration in fish tissues (Goel et al. 1988; Almeida et al. 2001). Total protein concentration ( $\mathrm{mg} \mathrm{g}^{-1}$ of wet tissue; mean $\pm \mathrm{SD}$ ) of different fish tissues collected from both contaminated and uncontaminated fishponds have been presented in Figs $2-5$. The pattern for total protein expression for different fish tissues collected from both contaminated and uncontaminated sites for all the species is: liver $>$ gill $\geq$ muscle $>$ brain. It is 
interesting to note that total protein concentration is always found to be invariably higher in uncontaminated fish tissues.

It can be inferred from the study of total protein that IMCs thriving at ECWs are facing potential stress from metals. At this point it is noteworthy to mention that the ECW areas are well-known for good fish yield through wastewater pisciculture and the present work has been initiated with a basic question how the fish yield is so good even though the ambient water is contaminated with such a high concentrations of elements.

Here the study of stress protein metallothionein comes handy. The tissue specific expression of metallothionein is given in Figs $6-9$. The pattern for MT expression for different fish tissues collected from wastewater-fed fishponds is: liver $>$ muscle $>$ gill $>$ brain and for freshwater-fed fish pond it is: liver $>$ gill $>$ muscle $>$ brain. The tissue specific metallothionein expression has almost complemented the tissue specific metal concentration for IMCs previously reported from this area (Aich et al. 2011).

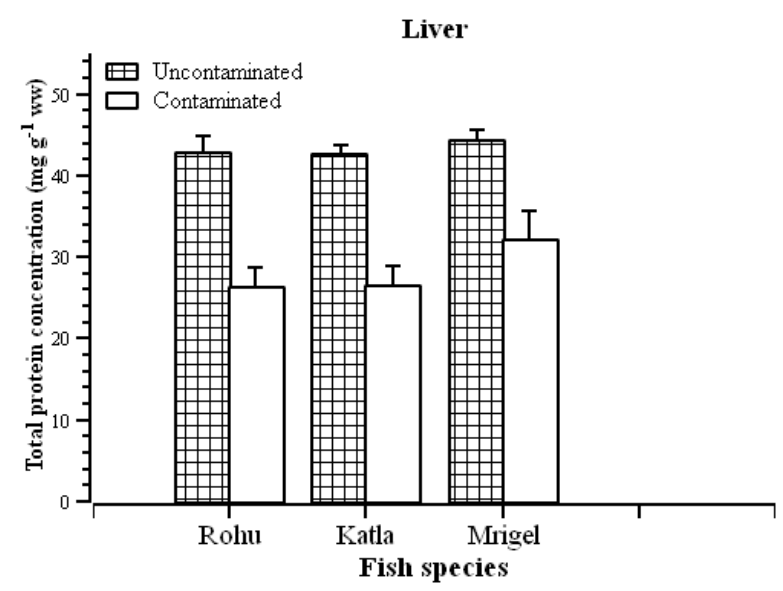

Fig. 2. Total protein content ( $\mathrm{mg}^{-1}$ of wet tissue; mean $\pm S D)$ in liver of IMCs collected from both uncontaminated and contaminated (wastewaterfed) fishponds

Gill

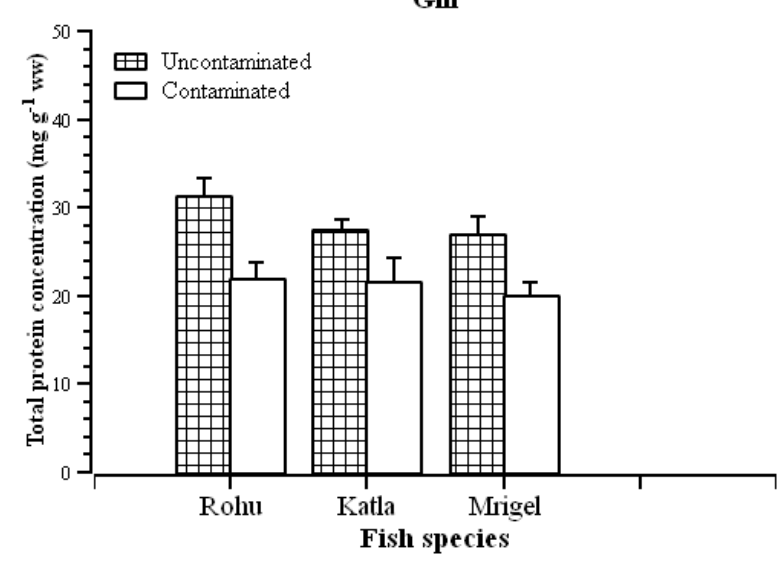

Fig. 3. Total protein content ( $m g \mathrm{~g}^{-1}$ of wet tissue; mean $\pm S D)$ in gill of IMCs collected from both uncontaminated and contaminated (wastewaterfed) fishponds

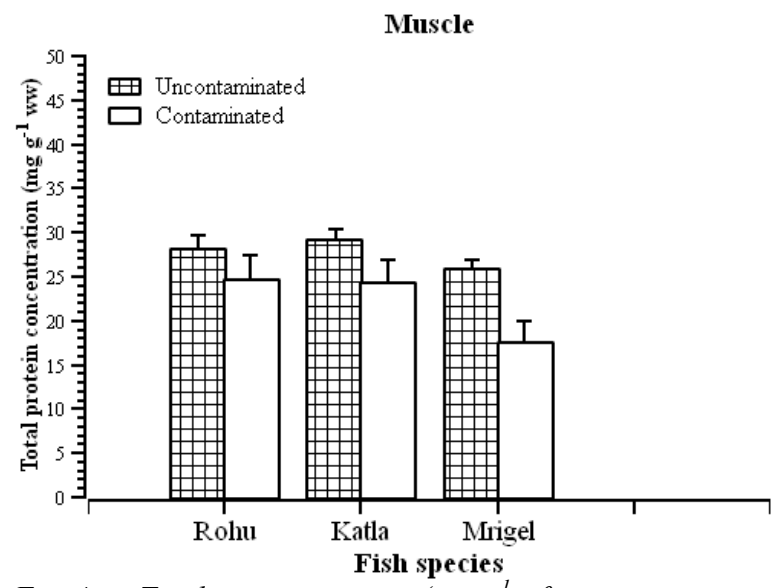

Fig. 4. Total protein content ( $\mathrm{mg} \mathrm{g}^{-1}$ of wet tissue; mean $\pm S D)$ in muscle of IMCs collected from both uncontaminated and contaminated (wastewaterfed) fishponds

\section{Brain}

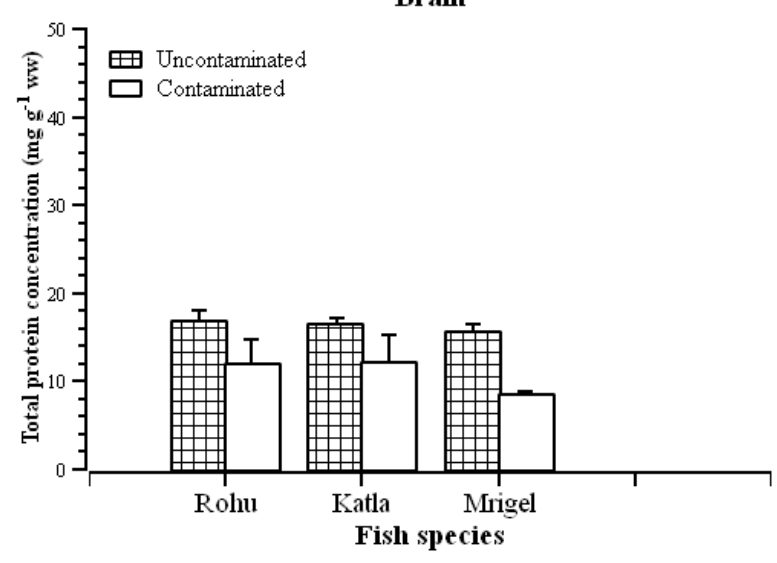

Fig. 5. Total protein content ( $m g \mathrm{~g}^{-1}$ of wet tissue; mean $\pm S D$ ) in brain of IMCs collected from both uncontaminated and contaminated (wastewaterfed) fishponds

These findings are similar to those obtained by Stewart et al. (1996) where metallothionein was found to be positively correlated with $\mathrm{Cd}, \mathrm{Zn}$ and $\mathrm{Cu}$ in kidney and liver of adult lesser-black backed gulls, Larus fuscus. There is increasing evidence that an elevated level of metallothionein in fish indicates that the fish has been exposed to metals like $\mathrm{Cu}, \mathrm{Zn}, \mathrm{Cd}$ or Hg (Roch et al. 1982; Olsson and Haux 1986; Sulaiman et al. 1991; Hylland et al. 1992). In teleosts at least four metallothionein genes have been characterized that share common promoter regions and carry several metal responsive elements (MREs), which effectively bind metal transcription factors (MTF) (Kling and Olsson 1993). Previous findings have also confirmed that pre-exposure of an organism or cultured cells to metals can enhance the tolerance to subsequent metal induced toxicities by inducing metallothionein (Irato et al. 1996; Dethloff et al. 1999; Wu et al. 2000; Wu and Hwang 2003; Zhang et al. 2006). This de novo synthesis of metallothionein, which is dose and time dependent, results in increased 
chelation of heavy metals rendering the heavy metals less toxic (Wicklund-Glynn and Olsson 1991).

Though the binding affinity for metals to thionein is the highest for $\mathrm{Hg}$ followed by $\mathrm{Cu}, \mathrm{Cd}$ and $\mathrm{Zn}$, the inducing ability of these metals for metallothionein is quite different. In most studied vertebrates $\mathrm{Zn}$ has been found to be the most potent inducer of metallothionein followed by $\mathrm{Cd}$ and $\mathrm{Hg}$, while $\mathrm{Cu}$ is often found to be a poor inducer (Olsson 1996). The present findings indicate that higher bioavailability of some metals like $\mathrm{Zn}$ and $\mathrm{Cu}$ induced higher metallothionein expression in the fishes collected from contaminated fishponds, which effectively chelated both bioactive and non-bioactive metals, reflected by higher metallothionein concentrations in the concerned organs.

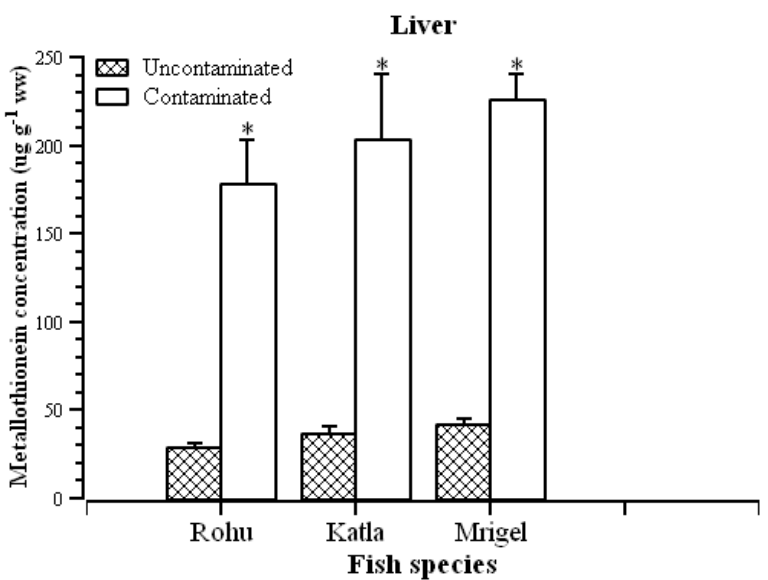

Fig. 6. Metallothionein content ( $\mu g g^{-1}$ of wet tissue; mean $\pm S D)$ in liver of IMCs collected from both uncontaminated and contaminated (wastewaterfed) fishponds. Significant difference in MT expression among different fish species from respective controls for the same time period has been indicated by asterisks $(*)(p<0.05$, ANOVA with Tukey's comparisons)

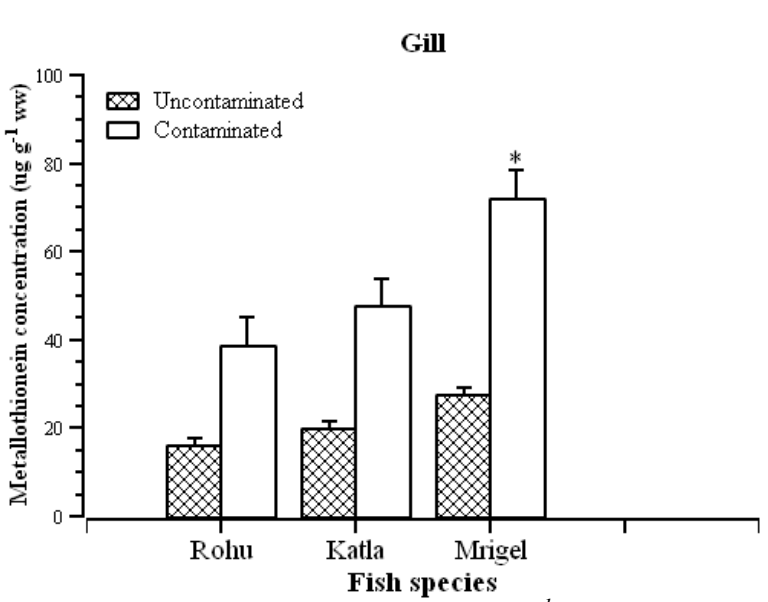

Fig. 7. Metallothionein content ( $\mu \mathrm{g} g^{-1}$ of wet tissue; mean $\pm S D$ ) in gill of IMCs collected from both uncontaminated and contaminated (wastewaterfed) fishponds. Significant difference in MT expression among different fish species from respective controls for the same time period has been indicated by asterisks (*) $(p<0.05$, ANOVA with Tukey's comparisons)
These findings conform to the previous studies, where metallothionein levels have been found to increase with environmental exposure to heavy metal mixtures, mainly containing $\mathrm{Cu}$ and $\mathrm{Zn}$ (Roch et al. 1982; Hogstrand et al. 1991). Moreover, it has been argued that the toxicity of heavy metals such as $\mathrm{Cd}$ and $\mathrm{Hg}$ will only occur when the binding capacity of metallothionein is exceeded and the excess heavy metal is free to bind some other proteins in the cell.

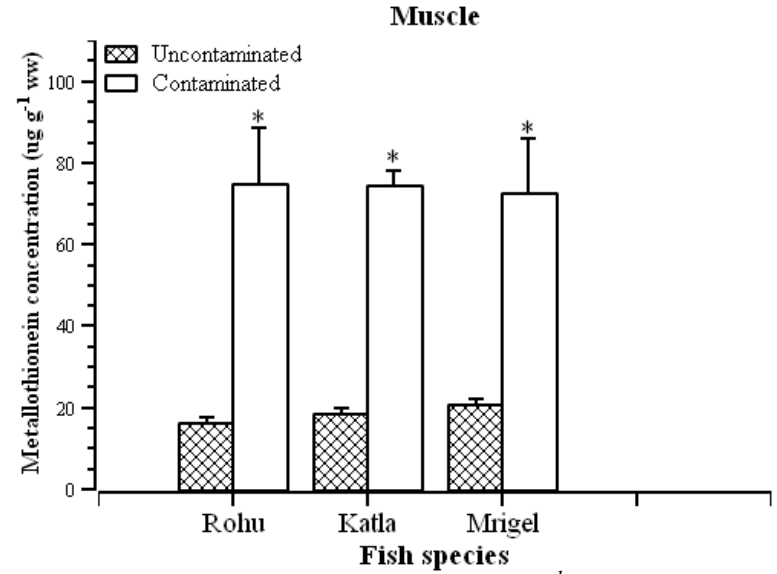

Fig. 8. Metallothionein content ( $\mu g g^{-1}$ of wet tissue; mean $\pm S D$ ) in muscle of IMCs collected from both uncontaminated and contaminated (wastewater-fed) fishponds. Significant difference in MT expression among different fish species from respective controls for the same time period has been indicated by asterisks (*) $(p<0.05$, ANOVA with Tukey's comparisons)

Brain

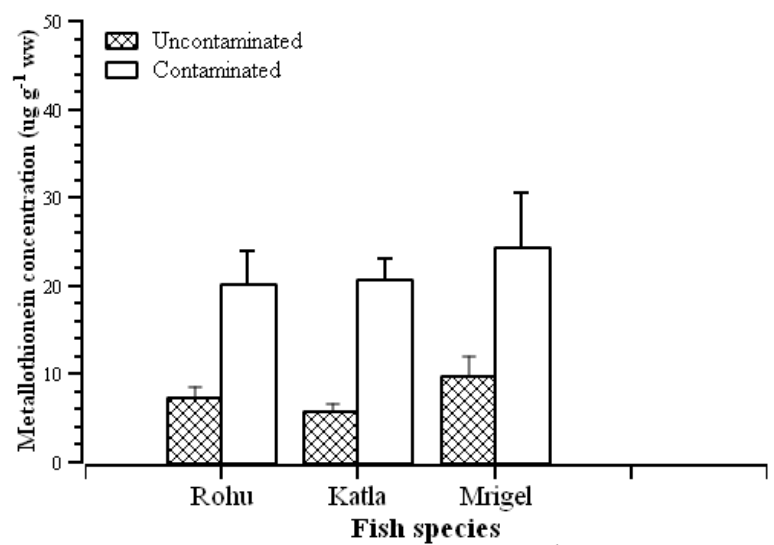

Fig. 9. Metallothionein content ( $\mu g g^{-1}$ of wet tissue; mean $\pm S D$ ) in brain of IMCs collected from both uncontaminated and contaminated (wastewaterfed) fishponds

There it seems to be a threshold level for heavy metal toxicity. However, it has been argued that the kinetics of metal uptake and metallothionein synthesis are both to be taken into account, whereby the pathological effects would appear when the rate of metal uptake exceeds the rate of metallothionein synthesis (McCarter et al. 1982). Thus it can be inferred that IMCs thriving at ECWs evolved in a manner to express higher metallothionein to arrest excess elements in the system that would otherwise interfere with the physiological processes. Liver was 
the site for the highest metallothionein synthesis and thereby it arrested the highest portions of elements which entered the fish biosystem to maintain the proper metal homeostasis and to lessen the stress, otherwise intolerable.

\section{Conclusions}

Since its discovery metallothionein has been subjected to various studies and an increasing amount of information on the induction and regulation of this protein by metals in the environment provides a suitable system for monitoring purposes. Though metallothionein regulation is fairly complex, considering certain factors such as the period of sexual maturation and ambient temperature fluctuation, it promises to be a potent indicator for environmental monitoring.

So far as IMCs of ECWs are concerned, there remains a potential stress due to exposure to adverse ambient conditions loaded with metals and that was reflected in the lower total protein concentration in all the wastewater-fed fish tissues. Despite this stressful ambient environment, fish yield in wastewater-fed fish ponds in ECW was 2.85 metric ton per ha of water body per annum and this could be attributed to the fact that fish species thriving at ECWs are still able to effectively trap the metals by metallothionein, or, in another sense, the stress due to higher ambient metal concentration is still within the threshold limit.

\section{Acknowledgements}

Authors thankfully acknowledge the infrastructural support extended by the Director of Public Instruction and the Director of Technical Education Govt. of West Bengal, India. Authors also express their kindest thank and acknowledge to CSIR for providing necessary funds.

\section{References}

ABDELMEGUID, N., KHEIRALLAH, A.M., ABOU-SHABANA ADHAM, K. \& ABDEL-MONEIM, A. Histochemical and biochemical changes in liver of Tilapia zilli $\mathrm{G}$. as a consequence of water pollution. Online Journal of Biological Science, 2002, 2, 224-229.

AICH, A., CHAKRABORTY, A., SUDARSHAN, M., CHATTOPADHYAY, B. \& MUKHOPADHYAY, S.K. Study of trace metals in Indian major carp species from wastewater-fed fishponds of East Calcutta Wetlands. Aquaculture research, 2011, 1-13. doi:10.1111/j.13652109.2011.02800.x http://dx.doi.org/10.1111/j.13652109.2011.02800.x

ALMEIDA, J.A., NOVELLI, E.L.B DAL-PAI SILVA M. \& ALVES-JUNIOR, R. Environmental cadmium exposure and metabolic responses of the Nile tilapia Oreochromis niloticus. Environmental Pollution,
2001, 114, 169-175. http://dx.doi.org/10.1016/S02697491(00)00221-9

BREMNER, I. \& BEATTIE, J.H. Metallothionein and the trace minerals. Annual Review of Nutrition, 1990, 10, 63-83.

http://dx.doi.org/10.1146/annurev.nu.10.070190.000431

CANLI, M. \& ERDEM, C. Mercury toxicity and effects of exposure concentration and period on mercury accumulation in tissues of a tropical fish Tilapia niloticus (L.). Turkish Journal of Zoology, 1994, 18, 233-239.

CHATTERJEE, S., CHATTOPADHYAY, B., MUKHOPADHYAY, S.K. Trace metal distribution in tissues of cichlids (Oreochromis niloticus and $O$. mossambicus) collected from wastewater-fed fishponds in East Calcutta Wetlands, A Ramsar site, Acta Ichthyologica Piscatoria, 2006, 36, 119-125.

CHATTOPADHYAY, B., CHATTERJEE, A., MUKHOPADHYAY, S.K. Bioaccumulation of metals in the East Calcutta wetland ecosystem, Aquatic Ecosystem Health \& Management, 2002, 5, 191-203. http://dx.doi.org/10.1080/14634980290031848

CICIK, B. \& ENGIN, K. The effects of cadmium on levels of glucose in serum and glycogen reserves in the liver and muscle tissues of Cyprinus carpio (L., 1758). Turkish Journal of Veterinary and Animal Science, 2005, 29, 113117.

DERANGO, R. \& PAGE, J. The quantitation of coupled bead antibody by enzyme-linked immunosorbent assay. Journal of Immunoassay, 1996, 17, 145-153. http://dx.doi.org/10.1080/01971529608005785

DETHLOFF, G.M., DANIEL, S., JONATHAN, T.H. \& HOWARD, C.B. Alterations in physiological parameters of rainbow trout (Oncorhynchus mykiss) with exposure to copper and coper/zinc mixtures. Ecotoxicology and Environmental Safety, 1999, 42, 253-264. http://dx.doi.org/10.1006/eesa.1998.1757

DIANA, J.S. An experimental analysis of the metabolic rate and food utilization of northern pike. Comparative Biochemistry and Physiology, 1982, 71, 395398. http://dx.doi.org/10.1016/0300-9629(82)90424-8

FAROMBI, E.O., ADELOWO, O.A. \& AJIMOKO Y.R. Biomarkers of oxidative stress and heavy metal levels as indicators of environmental pollution in African cat fish (Clarias gariepinus) from Nigeria Ogun river. International Journal of Environmental Research and Public Health, 2007, 4, 158- $\quad 165$.

http://dx.doi.org/10.3390/ijerph2007040011

GHOSH, S.K. 2004. Traditional and commercial practices in sustainable development and conservation of man and wetlands. In Knowledge marketplace reports: The $3^{\text {rd }}$ IUCN world conservation congress, Bangkok, Thailand, pp. 1-6.

GOEL, S.K., RAO, G.S. \& PANDYA, K.P. Hepatotoxic effects elicited by $\mathrm{n}$-haxane or $\mathrm{n}$ haptane. Journal of applied Toxicology, 1988, 8, 81-84. http://dx.doi.org/10.1002/jat.2550080203 
HAMER, D.H. Metallothionein. Annual Review of Biochemistry, 1986, 55, 913-951. http://dx.doi.org/10.1146/annurev.biochem.55.1.913

HEATH, A. 1995. Water pollution and fish physiology. CRC press Inc. Florida.

HOGSTRAND, C., LITHNER, G. \& HAUX, C. 1991. The importance of metallothionein for the accumulation of copper, zinc and cadmium in environmentally exposed perch, Perca fluviatilis. Pharmacology \& Toxicology, 1991, 68, 492-501. http://dx.doi.org/10.1111/j.1600-0773.1991.tb01275.x

HORNITZKY, M. \& SEARSON, J. The relationship between the isolation of Brucella abortus and serological status of infected, non vaccinated cattle. Australian Veterinary Journal, 1986, 63, 172-174. http://dx.doi.org/10.1111/j.1751-0813.1986.tb02966.x

HYLLAND, K., HAUX, C. \& HOGSTRAND, C. Hepatic metallothionein and heavy metals in dab Limanda limanda from the German Bright. Marine Ecology Progress $\begin{array}{llll}\text { Series. } & 1992, & \text { 89-96. }\end{array}$ http://dx.doi.org/10.3354/meps091089

IRATO, P., STURNIOLO, G.C., GIACON, G., MAGRO, A., D'INCA, R., MESTRINER, C. \& ALBERGONI, V. Effect of zinc supplementation on metallothionein, copper and zinc concentrations in various tissues of copper-loaded rats. Biological Trace Elemental Research, 1996, 51, 87-96. http://dx.doi.org/10.1007/BF02790151

JANA, S. \& SAHANA, S.S. Effects of $\mathrm{Cu}, \mathrm{Cd}$ and $\mathrm{Cr}$ cations on the freshwater fish Clarias batrachus (L). Physiologia Bohemoslovaca, 1988, 37, 79-82.

KALAY, M. \& CANLI, M. Elemination of essestioal $(\mathrm{Cu}, \mathrm{Zn})$ and non-essential $(\mathrm{Cd}, \mathrm{Pb})$ metals from tissues of a freshwater fish Tilapia zilli. Turkish Journal of Zoology, 2000, 24, 429-436.

KARIN, M. Metallothionein: protein in search of function. Cell, 1985, 41, 9-10. http://dx.doi.org/10.1016/0092-8674(85)90051-0

KLING, P. \& OLSSON, P.E. Metal regulation of the rainbow trout metallothionein-A gene. In: proceedings of the Seventh International Symposium on Responses of Marine Organisms to Pollutants, 1993.

LINDE-ARIAS, A.R., INÁCIO, A.F., ALBURQUERQUE, C.D., FREIRE, M.M. \& MOREIRA, J.C. Biomarkers in an invasive fish species, Oreochromis niloticus, to assess the effects of pollution in a highly degraded Brazilian River. Science of the Total Environment, 2008, 399, 186-192. http://dx.doi.org/10.1016/j.scitotenv.2008.03.028

LOWRY, O.H., ROSENBROUGH, N.M., FARR, A.L. \& RANDALL, R.J. Protein measurement with Folin phenol reagent. Journal of Biological Chemistry, 1951, 193, 265 .

MCCARTER, J.A., MATHESON, A.T., ROCH, M., OLAFSON, R.W. \& BUCKLEY, J.T. Chronic exposure of coho salmon to sublethal concentrations of copper II: Distribution of copper between high and low-molecular weight proteins in the liver cytosol and the possible role of metallothionein in detoxification. Comparative Biochemistry and Physiology, 1982, 74C: 133-137.

OLSSON, P.E. \& HAUX, C. Increased hepatic metallothionein content correlates to cadmium accumulation in environmentally exposed perch (Perca fluviatilis). Aquatic Toxicology, 1986, 9, 231-242. http://dx.doi.org/10.1016/0166-445X(86)90011-1

OLSSON, P.E., HYLLNER, S.J., ZAFARULLAH, M., ANDERSSON, T. \& GEDAMU, L. Differences in metallothionein gene expression in primary cultures of rainbow trout hepatocytes and the RTH-149 cell line. Biochimica et Biophysica Acta: Protein Structure and Molecular Enzymology, 1990, 1049, 78-82.

OLSSON, P.E. 1996. Metallothionein in fish: induction and use in environmental monitoring, In: Toxicological aquatic pollution: physiological, molecular and cellular approaches, Taylor, E.W. (Ed.), Cambridge, Cambridge University Press, UK. http://dx.doi.org/10.1017/CBO9780511735516.010

RAUF, A., JAVED, M. \& UBAIDULLAH, M. Heavy metal levels in three major carps (catla catla, Labeo rohita and Cirrhina mrigala) from the river Ravi, Pakistan. Pakistan Veterinary Journal, 2009, 29, 24-26.

RAYCHAUDHURI, S., MISHRA, M., SALODKAR, S., SUDARSHAN, M. \& THAKUR, A.R. Traditional aquaculture practice at East Calcutta Wetland: the safety assessment. American Journal of Environmental Science, 2008, 4(2), 173-177. http://dx.doi.org/10.3844/ajessp.2008.173.177

ROCH, M., MCCARTER, J.A., MATHESON, A.T., CLARK, M.J.R. \& OLAFSON, R.W. Hepatic metallothionein in rainbow trout (Salmo Gairdneri) as an indicator of metal pollution in the Campbell River system. Canadian Journal of Fisheries and Aquatic Sciences, 1982, 39, 1596-1601. http://dx.doi.org/10.1139/f82-215

ROESIJADI, G. Metallothionein and its role in toxic metal regulation. Comparative Biochemistry and Physiology, 1996, 113C, 117-123.

SORENSEN, E.M.B. 1991. Metal poisoning in fish. CRC Press, Boston, MA.

STEWART, F.M., FURNESS, R.W. \& MONTEIRO, L.R. Relationship between heavy metal and metallothionein concentrations in lesser black-backed gulls, Larus fuscus, and Cory's shearwater, Calonectris diomedea. Archives of Toxicology, 1996, 30, 299-305. http://dx.doi.org/10.1007/BF00212287

SULAIMAN, N., GEORGE, S. \& BURKE, M.D. Assessment of sublethal pollutant impact on flounders in an industrialized estuary using hepatic biochemical inducers. Marine Ecology Progress Series, 1991, 68, 207-212. http://dx.doi.org/10.3354/meps068207

WAALKES, M.P., CHERNOFF, S.B. \& KLAASSEN, C.D. Relative binding affinity of hepatic metallothionein for metals. Toxicology Letters, 1984, 20, 33-39. http://dx.doi.org/10.1016/0378-4274(84)90179-6 
WICKLUND-GLYNN， A. \& OLSSON, P.E. Cadmium turnover in minnows (Phoxinus phoxinus) exposed to waterborne cadmium. Environmental Toxicology and Chemistry, 1991, 10, 383-394.

WONG, M.H. Ecological restoration of mine degraded soils, with emphasis on metal contaminated soils. Chemosphere, 2003, 50, 775-780. http://dx.doi.org/10.1016/S0045-6535(02)00232-1

WU, S.M. \& HWANG, P.P. Copper or cadmium pretreatment increases the protection against cadmium toxicity in tilapia larvae (Oreochromis mossambicus). Zoological studies, 2003, 42, 179-185.

WU, S.M., WENG, C.F., HWANG, J.C., HUANG, C.J. \& HWANG, P.P. Metallothionein induction in early stage of tilapia (Oreochromis mossambicus). Physiological and Biochemical Zoology, 2000, 73, 531-537. http://dx.doi.org/10.1086/317754

ZHANG, X.Y., GAO, X., LI, Y. \& FAN, X.D. Metallothionein induction by $\mathrm{Cd}(\mathrm{II})$ and $\mathrm{Zn}(\mathrm{II})$. Chinese Chemical Letters, 2006, 17, 269-272.

Utpal Singha Roy, Assistant Professor in Zoology, Department of Zoology, Durgapur Government College, West Bengal, India.

Main research area: wetland ecology and ecotoxicology.

E-mail: $\quad$ srutpal@gmail.com.

Prof. Dr. Buddhadeb Chattopadhyay, Principal, Government College of Engineering and Leather Technology, Salt Lake City, Kolkata, West Bengal, India.

Main research area: limnology and assessment of environmental pollution.
Prof. Dr. Siddhartha Datta, Pro-Vice chancellor, Jadavpur University, Kolkata, India.

Main research area: chemical engineering and ecotoxicology.

Dr. Subhra Kumar Mukhopadhyay, Principal, Hooghly Mohsin College, Chinsurah, West Bengal, India. Main research area: wetland ecology and ecotoxicology. 